\title{
COMPARISON BETWEEN DIFFERENT METHODS FOR MEASURING BODY FAT AFTER A WEIGHT LOSS PROGRAM
}

\author{
COMPARAÇÃO ENTRE DIFERENTES MÉTODOS PARA MENSURAÇÃO DA GORDURA CORPORAL APÓS UM \\ PROGRAMADEPERDA DEPESO
}

Original Article

ARTIGO ORIGINAL

Artículo Original

\author{
COMPARACIÓN ENTRE DIFERENTES MÉTODOS PARA MEDICIÓN DE LA GRASA CORPORAL DESPUÉS DE UN \\ PROGRAMADEPÉRDIDA DEPESO
}

\author{
Pedro Jose Benito \\ (Physical Education Professional) \\ Carmen Gómez-Candela² \\ (Physician) \\ María Dolores Cabañas ${ }^{3}$ \\ (Physician) \\ Barbara Szendrei \\ (Physical Education Professional) \\ Eliane Aparecida Castro 1,4,5 \\ (Physical Education Professional) \\ on behalf of the PRONAF Study \\ Group
}

1. LFE Research Group. Department of Health and Human Performance. Faculty of Physical Activity and Sport Sciences. Universidad Politécnica de Madrid, Madrid, Spain.

2. Nutrition Department, IdiPAZ. University Hospital La Paz Research Institute, Madrid, Spain.

3. Department of Human Anatomy and Embryology. Medical Faculty. Complutense University of Madrid, Madrid, Spain

4. Department of Sports Sciences and Physical Conditioning, Faculty of Education, Universidad

Católica de la Santísima

Concepción, Concepción, Chile.

5. Health Promotion Graduate

Program. Universidade de Franca,

Franca, Brazil.

\section{Correspondence:}

Eliane Aparecida de Castro.

Rua dos Pracinhas, 2000, apto 01

Residencial Paraíso, Franca - SP,

14403-160, Brazil.

elianeaparecidacastro@gmail.com

\begin{abstract}
Introduction: Accurate and sensitive measurement of body composition is an important tool in the diagnosis and control of obesity. Objective: To compare body fat changes measured by dual-energy X-ray absorptiometry (DXA), bioelectrical impedance analysis (BIA), and skinfolds (SK) in healthy overweight adults in order to evaluate whether all three methods can be used during a weight loss program (WLP). Methods: Eighty-four men ( $n=36)$ and women $(\mathrm{n}=48)$, body mass index $25-29.9 \mathrm{~kg} / \mathrm{m}^{2}$, aged between $18-50$ years, non-smokers and sedentary, were randomly assigned to strength, endurance, combined strength plus endurance, or physical activity recommendations groups. All subjects followed a hypocaloric diet (25-30\% decrease in energy intake in terms of the total daily energy expenditure). The intervention lasted 22 weeks. Results: The highest correlation was obtained between DXA and SK when men and women were studied together $(r=0.864, p<0.01)$. In women, significant differences were found between DXA and BIA in fat percentage (underestimation of BIA $2.4 \%, \mathrm{p}<0.05$ ). The underestimation was more determinant for both fat percentage and fat mass in men, $13.2 \%$ versus $10.2 \%$, and $6.8 \mathrm{~kg}$ versus $4.2 \mathrm{~kg}$ between BIA and SK respectively $(p<0.05)$. All the procedures obtained similar results $(p>0.05)$ when changes in body fat caused by intervention were analyzed. However, considering results of the minimal difference compared to DXA, BIA showed the greatest sensitivity to detect changes in fat percentage and fat mass, while SK underestimated the changes, with a significantly lower percentage considered real $(p=0.01)$. Conclusion: The SK method seems to underestimate real changes, therefore DXA and BIA can serve as more effective tools to measure the change in fat percentage and fat mass during WLP. Level of evidence II, Diagnosis.
\end{abstract}

Keywords: Body composition; Exercise; Diet; Clinical trial; Overweight.

\section{RESUMO}

Introdução: A mensuração precisa esensível da composição corporal éuma importante ferramenta para o diagnóstico e controle da obesidade. Objetivo: Comparar as alterações da gordura corporal mensuradas através da absorciometria com raios-X de dupla energia (DEXA), análise da impedância bioelétrica (BIA) e dobras cutâneas (DC) em adultos saudáveis com sobrepeso, a fim de avaliar se os três métodos podem ser utilizados durante um programa de perda de peso (PPP). Métodos: Oitenta equatro homens $(n=36)$ e mulheres ( $n=48$ ) com indice de massa corporal entre $25-29,9 \mathrm{~kg} / \mathrm{m}^{2}$, idade entre 18-50 anos, não-fumantes e sedentários foram divididos aleatoriamente em grupos de de força, resistência, combinados de força mais resistência ou com recomendações de atividade física. Todos os indivíduos seguiram uma dieta hipocalórica (25-30\% de redução na ingestão energética em relação ao gasto energético total diário). A intervenção durou 22 semanas. Resultados: A maior correlação foi obtida entre a DEXA e DC quando homens e mulheres foram estudados juntos ( $r=0,864$, $p<0,01$ ). Foram encontradas diferenças significativas entre a DEXA e BIA no percentual de gordura (subestimação da BIA em $2,4 \%, p<0,05)$ nas mulheres. A subestimação foi mais determinante tanto para o percentual de gordura quanto para a massa gorda nos homens, $13,2 \%$ versus $10,2 \%$, e $6,8 \mathrm{~kg}$ versus $4,2 \mathrm{~kg}$ entre a BIA e DC, respectivamente $(p<0,05)$. Todos os procedimentos obtiveram resultados similares $(p>0,05)$ quando foram analisadas alterações na gordura corporal ocasionadas pela intervenção. No entanto, considerando os resultados da mínima diferença comparados à DEXA, a BIA apresentou maior sensibilidade para detectar mudanças no percentual de gordura e massa gorda, enquanto a DC subestimou as mudanças, com um percentual significativamente mais baixo considerado real ( $p=0,01)$. Conclusão: 0 método de DC parece subestimar as mudanças reais, portanto, a DEXA e BIA podem ser ferramentas mais eficazes para mensurar a alteração no percentual de gordura e a massa gorda durante um PPP. Nível de evidência II, Diagnóstico.

Descritores: Composição corporal; Exercício; Dieta; Ensaio Clínico; Sobrepeso.

\section{RESUMEN}

Introducción: La medición precisa y sensible de la composición corporal es una herramienta importante para el diagnóstico y control de la obesidad. Objetivo: Comparar las alteraciones de la grasa corporal medidas a través de la absorciometría con rayos X de doble energía (DXA), análisis de la impedancia bioeléctrica (BIA) y los pliegues cutáneos $(P C)$ en adultos saludables con sobrepeso, con el fin de evaluar si se pueden utilizar los tres métodos durante un programa de pérdida de peso (PPP). Métodos: Ochentay cuatro hombres y mujeres (varones $n=36$ y mujeres $n=48$ ), con indice de masa corporal entre $25-29,9 \mathrm{~kg} / \mathrm{m}^{2}$, edad entre 
18-50 años, no fumadores y sedentarios fueron divididos aleatoriamente en grupos de fuerza, resistencia, combinados de fuerza más resistencia o con recomendaciones de actividad física. Todos los individuos siguieron una dieta hipocalórica (25-30\% de reducción en la ingestión energética con relación al gasto energético total diario). La intervención duró 22 semanas. Resultados: La mayor correlación fue obtenida entre DXAy PC cuando hombres y mujeres fueron estudiados conjuntamente $(r=0,864, p<0,01)$. Se encontraron diferencias significativas entre DXA y BIA en el porcentual de grasa (subestimación de la BIA en 2,4\%, p<0,05) en las mujeres. La subestimación fue más determinante, tanto para el porcentual de grasa como para la masa grasa en los hombres, $13,2 \%$ versus $10,2 \%, y 6,8 \mathrm{~kg}$ versus $4,2 \mathrm{~kg}$ entre BIAy $P C$, respectivamente $(p<0,05)$. Todos los procedimientos obtuvieron resultados similares ( $p>0,05)$, cuando se analizaron alteraciones en la grasa corporal causadas por la intervención. Sin embargo, considerando los resultados de la mínima diferencia comparados a DXA, la BIA presentó mayor sensibilidad para detectar cambios en el porcentual de grasay masa grasa, mientras que la PC subestimó los cambios, con un porcentual significativamente más bajo considerado real ( $p=0,01$ ). Conclusión: El método de PC parece subestimar los cambios reales, por lo tanto, la DXA y la BIA pueden ser herramientas más eficaces para medir la alteración en el porcentual de grasa y masa grasa durante un PPP. Nivel de evidencia ll, Diagnóstico.

Descriptores: Composición Corporal; Ejercicio; Dieta; Ensayo Clínico; Sobrepeso.

\section{INTRODUCTION}

Accurate and sensitive measurement of body composition is necessary to assess the nutritional status within and between populations, as well as it is an important tool in the diagnosis and the follow up of obesity and metabolic disorders.

Although widely used methods, like the skinfold (SK) measurement ${ }^{1}$ and bioelectrical impedance analysis (BIA) 2,3 have limitations and low accuracy. ${ }^{3}$ Sex, gender, ethnicity, age and athletic orientation all affect skinfold formulae, which require various measurements from different locations. ${ }^{4}$ Skinfold thickness is also relatively inaccurate in obese individuals. ${ }^{5}$ Body composition analysis using BIA can be influenced by exercise, fluid intake, dehydration, and even smoking., ${ }^{6,7}$ However, BIA is widely available, inexpensive and without the requirement of a high-level operator training.

Dual-energy X-ray absorptiometry (DXA) was introduced and rapidly utilized as a criterion method of body composition assessment. ${ }^{8}$ DXA is a three-compartment model of fat mass (FTM) and two components of fat free mass (FFM), i.e., bone mineral content (BMC) and lean tissue mass (LTM). DXA, however, is not widely available outside of the clinical or research area. The most important drawbacks of the frequent use of this technique (DXA), the high cost of the equipment and the unnecessary radiation exposure of the patients, make DXA measurements as a monitoring tool during intervention programs questionable.

From a practical point of view, knowing the difference between the various ways of measuring, provides a way to compare and standardize the reference data, however to monitor a weight loss program it is more important to know whether the observed changes are similar with each technique. If there are differences among changes, the interpretation of these should include the technique used. The short-term precision of DXA body composition measurements varies slightly with the type of the tissue, with lean mass demonstrating better precision than fat mass. The coefficient of variation of whole-body lean mass measurements has been reported to be $\sim 1.0 \%$; whereas, for fat mass and percent body fat ranges between 0.8 and $2.7 \% .{ }^{9}$ However, the precision of BIA measures is poor, coefficient of variation for fat mass is $40 \%$, for fat percentage 24.2\% and for fat-free mass $18.6 \% .^{10}$

According to Toombs et al. ${ }^{9}$ the precision of the DXA to assess body composition was $0.4 \%, 1.0 \%$, and $0.9 \%$ (root-mean-square coefficient of variation) for lean mass, fat mass, and body fat percentage, respectively. Previous studies indicate that BIA tended to slightly overestimate the respective body composition compared to DXA. ${ }^{10}$

The aim of this study was to compare the changes of total body fat measured by BIA, SK and DXA in healthy overweight adults in order to evaluate whether all three methods can be used during a weight loss program.

\section{METHODS}

\section{Participants}

Subjects were healthy, overweight [body mass index (BMI) $\left.25-29.9 \mathrm{~kg} / \mathrm{m}^{2}\right]$, non-smoker, and sedentary (one or less exercise bout per week), not on a diet program, normoglycemic and women were all premenopausal and had regular menstrual cycles. Subjects with a background of systematic strength or endurance training (more than once a week moderate- to high-intensity training) during the last year before the study were excluded. The group $(n=84)$ consisted of young to middle-aged (range 18-50 years) men $(n=36)$ and women $(n=48)$ living in Madrid. The voluntary subjects who fulfilled the inclusion criteria and passed the baseline physical examination were stratified by age and sex and randomly assigned in four diet and exercise intervention group.

\section{Study overview}

This study was a 24-week-long intervention trial. The measurements were performed during the first week (baseline values, visit 1) for all subjects before starting to train, and after 22 weeks of training, during the week 24 (post-training values, visit 2). Menstrual cycles were controlled by diary to define the follicular and luteal phases when blood samples were taken. ${ }^{11}$

Diet prescription was performed by expert dietitians in the Nutrition Department of the University Hospital La Paz (HULP). All groups underwent an individualized and hypocaloric diet (between 1200 and $3000 \mathrm{kcal}$ ). The diet implied a 25\% reduction compared with the Total Daily Energy Expenditure (TDEE) ${ }^{12}$ measured using SenseWear Pro Armband $^{\mathrm{TM}}$ data.

All exercise groups followed a 3 times/wk training program during 22 weeks, supervised by certified personal trainers. The intensity was measured in RM (repetition maximum) for strength exercise or HRR (heart rate reserve) for endurance exercise and was of $50 \%$ and $60 \%$ of the 15RM and HRR for weeks 2-5 and 6-23, respectively. The total training session duration was of 51 min $15 \mathrm{~s}$ and 64 min for weeks 2-14 and 15-23, respectively. The number of circuit laps was two for weeks 2-14 and three for weeks 15-23. Each exercise lasted $45 \mathrm{~s}$, the time needed to complete 15 repetitions of the strength exercises. The recovery period between each exercise of the circuit and between laps for the circuit was of $15 \mathrm{~s}$ and $5 \mathrm{~min}$, respectively. To enlarge the knowledge about our clinical trial read the methodological publication. ${ }^{13}$

DXA, BIA and SK measures were taken the same day in which the participants went to the hospital on the first occasion.

In agreement with the guidelines of the Declaration of Helsinki regarding research on human subjects, prior to the onset of the investigation, 
participants read and signed an institutionally approved informed consent document. The protocol for this study was reviewed and approved by Human Research Review Committee of the University Hospital La Paz (PI-643). Registered under clinicaltrials.gov Identifier no. NCT01116856.

\section{BODY COMPOSITION MEASUREMENTS}

\section{Anthropometry and Skinfold}

Anthropometric measurements included height (1 cm, stadiometer; Holtain Limited, Crymych, United Kingdom) and body mass $(0.1$ kg, Lafayette Instruments Company, Lafayette, Indiana, USA). Four skinfold sites, triceps, biceps, subscapular and suprailiac were measured (after calibration), following the methods used by the International Society for the Advancement of Kinanthropometry (ISAK), and substitute the log of their sum applying the Durnin and Womersley ${ }^{14}$ equation for each age and sex, and using the Siri (1961) equation for transformation of body density in fat percentage. Fat mass was obtained by multiplying the fat percentage by body weight $(\mathrm{kg})$. Test-retest reliability was used to assess the precision error via calculation of total error $(T E=\sqrt{ } \Sigma$ ( (measurement 1 - measurement 2) ${ }^{2} / \mathrm{n}$ )). ${ }^{15}$ For anthropometric measures in our laboratory, the error was $0.43 \%$ for body fat percentage.

\section{DXA}

Body fat, fat free mass and bone mineral content were measured by Dual energy X-ray absorptiometry A Lunar iDXA ${ }^{\mathrm{TM}}$ scanner (GE Healthcare, Chalfont St Giles, Bucks., UK) with enCORE ${ }^{\mathrm{TM}} 2007$ v. 11 software was used to perform the total body scans. Prior to starting the scan, all metal objects were removed from the participants to ensure the accuracy of the measurement. Daily calibration of the scanner was performed using a phantom spine containing composites of bone, fat and lean tissue. Participants were positioned on the scanner bed according to the manufacturer's recommendations and instructed to remain as still as possible for the duration of the scan.

The precision error for DXA measures in our laboratory was $0.65 \%$ of body fat percentage.

\section{Bioelectrical impedance analysis}

BIA measurement was carried out prior to DXA scanning in all the subjects. A multi frequency bioelectrical impedance analyzer OMRON BF 306W analyzer (OMRON HEALTH- CARE Co., Ltd, Ukyo-ku, Kyoto, Japan), set to use the'normal' (nonathletic) proprietary algorithm, was used for the impedance measurement. In order to assure the exact prediction of the equations of BIA one followed the previous norms to improve the precision. ${ }^{16}$ Subjects stood with the ball and their heels were in contact with the metallic electrodes on the Xoor scale. Once weight was recorded, subjects were instructed to grasp the hand grips and hold them down by their sides so that the metallic electrodes were in contact with the palm and thumb.

The precision error for BIA measures in our laboratory was $0.52 \%$ of body fat percentage.

All measurements were done in agreement with the normal protocol at least $3 \mathrm{~h}$ after a meal (including drink), and subjects were requested to refrain from strenuous exercise $12 \mathrm{~h}$ prior to the measurements. Subjects were asked to empty their bladder before the measurements. Females were not measured during their menstrual period. ${ }^{17}$

\section{Statistical analyses}

All data were reported as mean \pm standard deviation (SD). A Kolgomorov Smirnov test was conducted and all data were normally distributed. Two-way ANOVA (2 sex x 3 categorized age) with repeated measures was used to determine differences between the methods (DXA, BIA, SK). Compound symmetry, or sphericity, was verified by the Mauchly test. When the assumption of sphericity was not met, the significance of $F$ ratios was adjusted according to the Greenhouse-Geisser procedure. Multiple comparisons of ANOVAs were made with the Bonferroni post-hoc test. To check the sensitivity of different methods to measure the change in body fat, graphics were drawn for bias, following the procedure described by Bland and Altman. Pearson's correlation was used to investigate the agreement between the three methods. Minimal Differences were calculated according to Weir ${ }^{18}$ and Chi-square test was used to identify any association among the different methods in the classification of significant fat loss. The statistical analysis was carried out with SPSS 15.0 software for Windows (SPSS Worldwide Headquarters, Chicago, IL) and the $\mathrm{p}<0.05$ level of significance was used to declare significance for all statistical procedures.

\section{RESULTS}

Subject characteristics are show in Table 1. Overall, men were taller $(+13,6 \mathrm{~cm} ; \mathrm{p}<0.05)$ and heavier $(+14.6 \mathrm{~kg} ; \mathrm{p}<0.05)$ than women and had a higher body mass index (BMI) $\left(+0.7 \mathrm{~kg} / \mathrm{m}^{2} ; \mathrm{p}<0.05\right)$.

There were not good correlations between DXA and all assessments of body composition using BIA and SK. The correlation values were lower for SK than BIA, increasing the association strength pooling the two visits. The highest correlation was obtained between DXA and SK when men and women together were calculated $(r=0.864 p<0.01)$, while the lowest in women between DXA and SK $(r=0.313 p<0.01)$. (Table 2)

In absolute terms, BIA results underestimated FM\% by $6.7 \%$, and $3.6 \mathrm{~kg}$, as well as the SK method by $4.3 \%$ and $1.8 \mathrm{~kg}$ when compared with DXA ( $p<0.05)$, but these results were highly dependent on the sex. Significant differences were only found in women when comparing DXA with BIA in fat percentage (underestimation of BIA 2.4\%, $\mathrm{p}<0.05$ ). For men in fat percentage and fat mass, underestimations were more determinant, $13.2 \%$ and $10.2 \%, 6.8 \mathrm{~kg}$ and $4.2 \mathrm{~kg}$ for BIA and SK respectively compared with DXA measurements $(p<0.05)$. When visits one and two were pooled for the analysis, a significant relationship was

Table 1. Subject characteristics (mean and standard deviation (SD).

\begin{tabular}{c|c|c|c|c|c|c}
\hline & \multicolumn{2}{|c|}{ Women $(\mathbf{n}=\mathbf{4 8})$} & \multicolumn{2}{c|}{ Men $(\mathbf{n}=\mathbf{3 6})$} & \multicolumn{2}{c}{ All $(\mathbf{n}=\mathbf{8 4})$} \\
\hline & Mean & SD & Mean & SD & Mean & SD \\
\hline Weight $(\mathrm{kg})$ & $73.6^{\mathrm{a}}$ & 6.2 & 88.2 & 8.0 & 79.4 & 10.0 \\
\hline Height $(\mathrm{cm})$ & $162.0^{\mathrm{a}}$ & 6.1 & 175.6 & 7.1 & 167.4 & 9.3 \\
\hline Age $($ years $)$ & 37.4 & 8.2 & 37.2 & 8.0 & 37.3 & 8.1 \\
\hline BMI $\left(\mathrm{kg} / \mathrm{m}^{2}\right)$ & $27.9^{\mathrm{a}}$ & 1.3 & 28.6 & 1.1 & 28.2 & 1.3 \\
\hline a. Significant differences with men $(\mathrm{p}<0.05)$.
\end{tabular}

Table 2. Summary of the association (Pearson correlation) among DXA, BIA and SK at the two visits and total.

\begin{tabular}{|c|c|c|c|c|c|c|c|}
\hline & & \multicolumn{2}{|c|}{ Women } & \multicolumn{2}{|c|}{ Men } & \multicolumn{2}{|c|}{ All } \\
\hline & & $r$ & $p$ & $r$ & $p$ & $r$ & $p$ \\
\hline DXA FM (Kg) V1 & - BIA FM (Kg) V1 & 0.342 & 0.02 & 0.199 & 0.34 & 0.227 & $0.06^{*}$ \\
\hline DXA FM (Kg) V1 & - SKFM (Kg) V1 & 0.301 & $0.05^{*}$ & 0.102 & 0.61 & 0.199 & 0.10 \\
\hline DXA FM (\%) V1 & $-\quad$ BIA FM (\%) V1 & 0.304 & $0.05^{*}$ & 0.142 & 0.50 & 0.205 & $0.09^{*}$ \\
\hline DXA FM (\%) V1 & $-\quad$ SK FM (\%) V1 & 0.131 & 0.40 & 0.085 & 0.67 & 0.131 & 0.28 \\
\hline DXA FM (Kg) V2 & - BIA FM (Kg) V2 & -0.049 & 0.75 & 0.266 & 0.18 & 0.077 & 0.53 \\
\hline DXA FM (Kg) V2 & - SK FM (Kg) V2 & -0.040 & 0.80 & 0.117 & 0.56 & 0.045 & 0.71 \\
\hline DXA FM (\%) V2 & - $\quad$ BIA FM (\%) V2 & 0.034 & 0.83 & 0.181 & 0.37 & 0.101 & 0.41 \\
\hline DXA FM (\%) V2 & - $\quad$ SK FM (\%) V2 & 0.094 & 0.55 & -0.022 & 0.91 & 0.099 & 0.42 \\
\hline \multicolumn{2}{|c|}{ Pooled V1 and V2 } & \multicolumn{2}{|c|}{$n=48$} & \multicolumn{2}{|c|}{$n=36$} & \multicolumn{2}{|c|}{$n=84$} \\
\hline DXA FM (Kg) & - BIA FM (Kg) V1\&V2 & 0.825 & $<0.01$ & 0.751 & $<0.01$ & 0.798 & $<0.01$ \\
\hline DXA FM (Kg) & - SK FM (Kg) V1\&V2 & 0.313 & $<0.01$ & 0.476 & $<0.01$ & 0.327 & $<0.01$ \\
\hline DXA FM (\%) & - BIA FM (\%) V1\&V2 & 0.829 & $<0.01$ & 0.815 & $<0.01$ & 0.756 & $<0.01$ \\
\hline \multirow[t]{2}{*}{ DXA FM (\%) } & - SK FM (\%) V1\&V2 & 0.636 & $<0.01$ & 0.777 & $<0.01$ & 0.864 & $<0.01$ \\
\hline & & \multicolumn{2}{|c|}{$n=96$} & \multicolumn{2}{|c|}{$n=72$} & \multicolumn{2}{|c|}{$n=168$} \\
\hline
\end{tabular}

In bold no significant ( $p>0.05)$; ${ }^{*}$ Tendency to significance. 
found between genders, age and measurement procedure in fat mass $[F(2.456)=4.204$ with $p=0.011]$, but not in fat percentage $[F(2.589)=1$. 001 with $p>0.05$ ], in which an interaction was found between methods of measurement and age $[F(2.589)=6.386$ with $p=0.001]$. (Table 3 )

In women significant differences were found, both in fat percentage and fat mass between BIA and DXA values, in subjects of 18-30 years $(p<0.05)$. SK showed differences with DXA for 18-30 years, in fat mass $(p<0.05)$. In men, BIA and SK showed significant differences with DXA almost in all ages $(p<0.001)$, except in the groups of $41-50$ years in fat mass. (Figure 1)

On the other hand, when the change of fat caused by intervention was analyzed, as $\mathrm{kg}$ or as percentage, all the procedures obtained similar results $(p>0.05)$. The changes obtained in fat mass with the different methods were $5.7 \pm 3.5 \mathrm{~kg}, 5.7 \pm 3.4 \mathrm{~kg}, 5.8 \pm 3.4 \mathrm{~kg}$ and $4.9 \pm 3.5 \%, 4.9 \pm 3.3 \%, 4.6 \pm 3.4 \%$ for DXA, BIA and SK respectively. (Figure 2, data not shown)

The Bland and Altman plots indicate that both BIA and SK were valid procedures with regard to the DXA to assess the fat change produced by an intervention or weight loss strategy. The differences were not significant between these three techniques in the observed change. When comparing observed changes between DXA and BIA the value of the difference was not significant, $0.2 \mathrm{~kg}(0.3 \%$ with $p>0.05)$. When DXA and SK were compared, the value of the latter was not significant either $-0.3 \mathrm{~kg}(0.1 \%$ with $p>0.05)$. (Figure 3$)$

In any intervention, to define the difference considered real, which reflects a real change and not a difference that is within what might be reasonably expected given the measurement error of any test is most important. ${ }^{18}$ The results of the minimal difference are presented in the Table 4. BIA showed the greatest sensitivity to detect changes in fat percentage and fat mass. When compared to the adopted standard measure (DXA), SK underestimates the changes, with a significantly lower percentage considered real $(p<0.05)$.

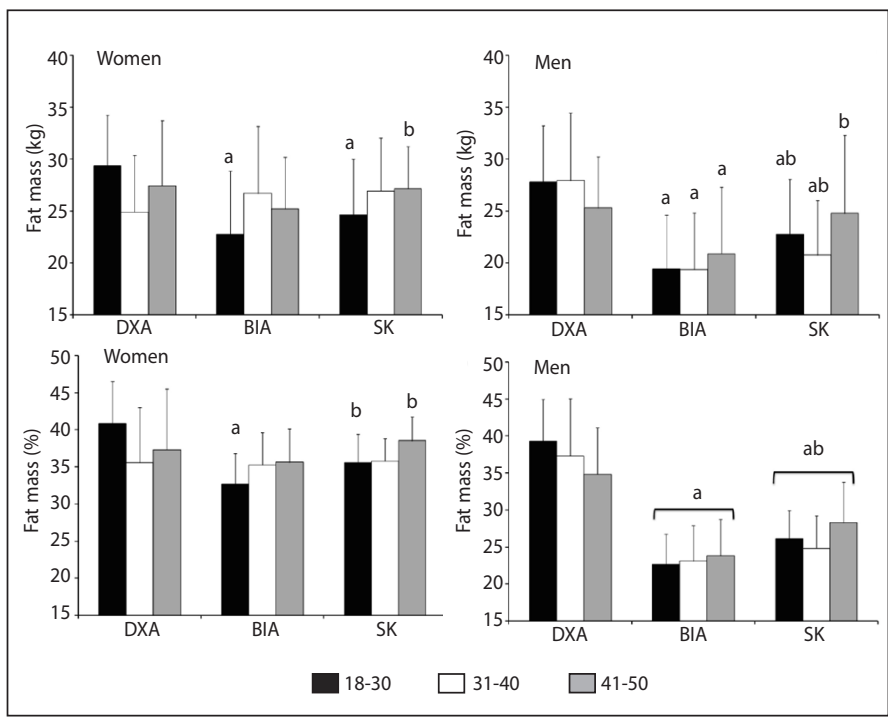

Figure 1. Differences among DXA, BIA and SK by categorized aged for men and women, in fat mass (FM) in kilograms (kg) and percentage (\%). a. Significant differences with DXA ( $p<0.05)$. b. Significant differences with BIA $(p<0.05)$

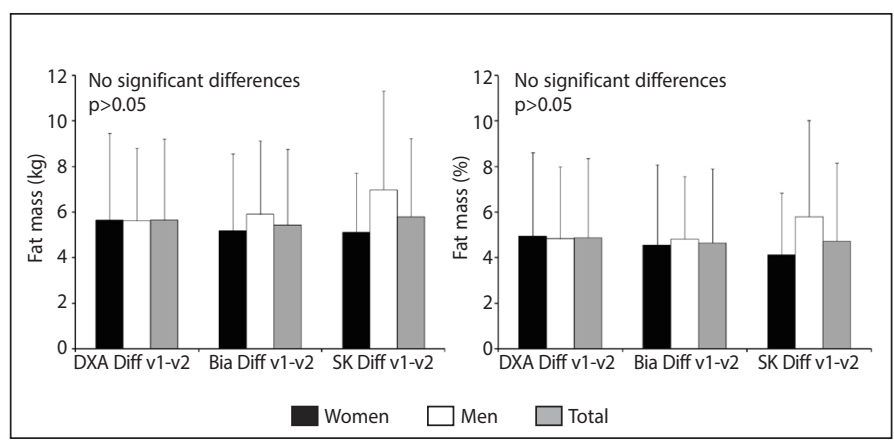

Figure 2. DXA, BIA and SK differences between visit 1 and visit 2 categorized by sex in fat mass (FM) in kilograms (kg) and percentage (\%).

Table 3. DXA, BIA and SK measurements of fat mass (FM) in kilograms (kg) and percentage (\%) in men and women; age 18-50 years; $(\mathrm{n}=84)$ at visit one (V1), second visit (V2), and pooling $\mathrm{V} 1+\mathrm{V} 2 / 2$ (Total).

\begin{tabular}{|c|c|c|c|c|c|c|c|c|c|c|c|c|}
\hline & \multicolumn{4}{|c|}{ Women $(n=48)$} & \multicolumn{4}{|c|}{ Men $(n=36)$} & \multicolumn{4}{|c|}{ All $(n=84)$} \\
\hline & Mean & SD & Min & Max & Mean & SD & Min & Max & Mean & SD & Min & Max \\
\hline DXA FM (Kg) V1 & 29.6 & 4.5 & 21.1 & 38.4 & 29.7 & 4.5 & 18.9 & 35.9 & 29.6 & 4.5 & 18.9 & 38.4 \\
\hline BIA FM (Kg) V1 & $27.9^{a}$ & 4.7 & 18.8 & 40.6 & $23.4^{a}$ & 5.0 & 14.4 & 33.4 & $26.1^{\mathrm{a}}$ & 5.3 & 14.4 & 40.6 \\
\hline SK FM (Kg) V1 & $29.1^{b}$ & 3.9 & 17.7 & 39.2 & $26.1^{\mathrm{ab}}$ & 5.9 & 14.2 & 41.9 & $27.9^{\#}$ & 5.0 & 14.2 & 41.9 \\
\hline DXA FM (\%) V1 & 39.7 & 6.6 & 27.6 & 50.1 & 39.1 & 6.2 & 26.7 & 47.5 & 39.5 & 6.4 & 26.7 & 50.1 \\
\hline BIA FM (\%) V1 & $37.2^{\mathrm{a}}$ & 3.4 & 29.0 & 42.3 & $26.1^{a}$ & 3.8 & 20.0 & 34.3 & $32.9^{\mathrm{a}}$ & 6.4 & 20.0 & 42.3 \\
\hline SK FM (\%) V1 & $38.9^{b}$ & 3.3 & 27.4 & 43.7 & $29.2^{\mathrm{ab}}$ & 4.3 & 19.7 & 38.4 & $35.0^{a b}$ & 6.1 & 19.7 & 43.7 \\
\hline DXA FM (Kg) V2 & 24.0 & 5.9 & 11.8 & 35.4 & 24.0 & 5.5 & 10.8 & 34.7 & 24.0 & 5.7 & 10.8 & 35.4 \\
\hline BIA FM (Kg) V2 & 22.6 & 5.8 & 9.4 & 41.1 & $16.9^{\mathrm{a}}$ & 4.6 & 9.0 & 27.6 & $20.3^{\mathrm{a}}$ & 6.0 & 9.0 & 41.1 \\
\hline SK FM (Kg) V2 & $24.0^{b}$ & 4.2 & 13.9 & 35.3 & $19.3^{\mathrm{ab}}$ & 5.1 & 10.5 & 33.6 & $22.1^{\mathrm{b}}$ & 5.1 & 10.5 & 35.3 \\
\hline DXA FM (\%) V2 & 34.8 & 8.5 & 18.0 & 49.2 & 34.2 & 6.9 & 18.1 & 45.2 & 34.6 & 7.8 & 18.0 & 49.2 \\
\hline BIA FM (\%) V2 & 32.5 & 5.2 & 18.1 & 42.5 & $20.7^{\mathrm{a}}$ & 3.9 & 14.4 & 31.9 & $27.8^{\mathrm{a}}$ & 7.5 & 14.4 & 42.5 \\
\hline SK FM (\%) V2 & $35.0^{\mathrm{b}}$ & 3.3 & 25.5 & 40.9 & $23.7^{a b}$ & 4.0 & 16.7 & 33.3 & $30.4^{a b}$ & 6.7 & 16.7 & 40.9 \\
\hline DXA FM (Kg) Total & 26.8 & 5.2 & 11.8 & 38.4 & 26.9 & 5.0 & 10.8 & 35.9 & 26.8 & 5.1 & 10.8 & 38.4 \\
\hline BIA FM (Kg) Total & 25.2 & 5.2 & 9.4 & 41.1 & $20.1^{\mathrm{a}}$ & 4.8 & 9.0 & 33.4 & $23.2^{\mathrm{a}}$ & 5.7 & 9.0 & 41.1 \\
\hline SK FM (Kg) Total & 26.6 & 4.1 & 13.9 & 39.2 & $22.7^{\mathrm{ab}}$ & 5.5 & 10.5 & 41.9 & $25.0^{\mathrm{ab}}$ & 5.1 & 10.5 & 41.9 \\
\hline DXA FM (\%) Total & 37.3 & 7.5 & 18.0 & 50.1 & 36.6 & 6.5 & 18.1 & 47.5 & 37.0 & 7.1 & 18.0 & 50.1 \\
\hline BIA FM (\%) Total & $34.9^{\mathrm{a}}$ & 4.3 & 18.1 & 42.5 & $23.4^{\mathrm{a}}$ & 3.8 & 14.4 & 34.3 & $30.3^{\mathrm{a}}$ & 7.0 & 14.4 & 42.5 \\
\hline SK FM (\%) Total & 36.9 & 3.3 & 25.5 & 43.7 & $26.4^{\mathrm{ab}}$ & 4.2 & 16.7 & 38.4 & $32.7^{\mathrm{ab}}$ & 6.4 & 16.7 & 43.7 \\
\hline
\end{tabular}




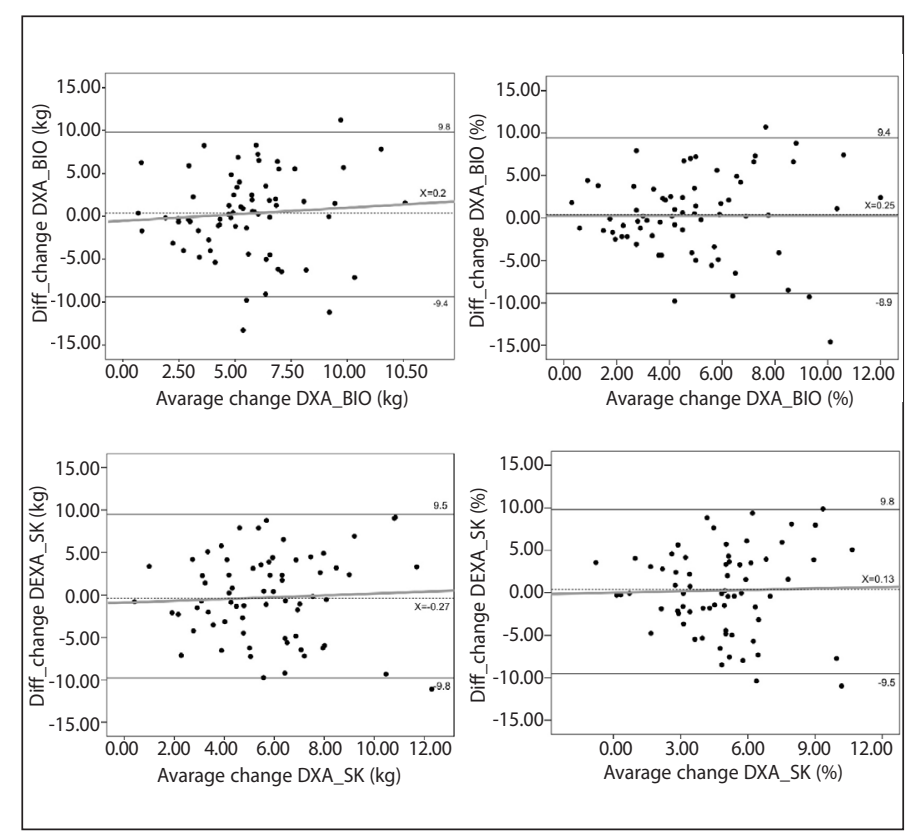

Figure 3. Bland-Altman plots at average of the difference between methods compared with DXA as reference in $\mathrm{kg}$ and percentage. The gray line indicates the trend of the differences.

Table 4. Minimum significant difference to observe change (MD) and scores $\chi^{2}$.

\begin{tabular}{c|c|c|c|c|c|c}
\hline & \multicolumn{2}{|c|}{ DXA } & \multicolumn{2}{c|}{ BIA } & \multicolumn{2}{c}{ SK } \\
\hline & $\mathbf{k g}$ & $\%$ & $\mathbf{k g}$ & $\%$ & $\mathbf{k g}$ & $\%$ \\
\hline MD & 1.17 & 1.14 & 1.01 & 0.99 & 1.02 & 1.01 \\
\hline \% of people greater than the MD & $90 \%$ & $90 \%$ & $94 \%$ & $94.1 \%$ & $90.8 \%$ & $82.7 \%$ \\
\hline DXA $\chi^{2}$ & - & - & 0.359 & 0.571 & 0.482 & $0.010^{a}$ \\
\hline BIA $\chi^{2}$ & 0.359 & 0.571 & - & - & 0.068 & 0.631 \\
\hline
\end{tabular}

a. Significant association with DXA $(p<0.05)$.

\section{DISCUSSION}

In our study we compared three methods (DXA, BIA and SK) to see if there are differences between the body fat changes observed during a diet and exercise program. Our data clearly showed differences in the change of fat were comparable; despite SK method seems to underestimate real changes induced by weight loss program. This study has a practical point, suggests that a frequently used technique as the BIA is also good tool to follow up a weight loss program.

Previous studies have shown that differences between indirect anthropometric variables and DXA in fat percentage and fat mass were dependent on sex and age. ${ }^{19}$ Differences between BIA and DXA also were greatest in subjects with higher amount of fat for both sex. ${ }^{8}$ In our case, greatest differences among the different methods were obtained in men, but in our study there was no greater difference dependent upon fat, possibly because of the sample analyzed, only overweight people.

In young adults comparative results between BIA and DXA remain controversial. Duz et al. ${ }^{20}$ studied college students aged 18-26 (104 men, 104 women) and found BIA underestimating body fat percentage by $4.8 \%$ in men and $9.2 \%$ in women, moreover the higher body fat percentage the subjects had the greater difference appeared in BIA values.

In our case, the BIA showed an underestimation of $2.4 \%$ compared with the DXA in women, furthermore this comparison in men was significantly greater, $13.3 \%$ (data not shown). This stronger male underestimation could be observed at the visit one and two. (Table 3) The explanation may be in a minor difference in fat percentage in our sample between men and women, or the actual equations of the
BIA devices may not completely represent the European population and should be partly revised. ${ }^{2}$ Something similar occurs with older adults, reporting the underestimation of the percentage of body fat in men and women, noted that the BIA measurements in percentage of body fat increased in subjects with high-percentage body fat, ${ }_{1}^{17}$ the interpretation of these studies differs only in the categorization of high fat mass. Previous results indicate that BIA is a valid method of body fat percentage in subjects with normal body weight or fat, but should be used with caution in women and in men with excess of body weight or fat.8,21,22

Moreover, Erselcan et al. ${ }^{23}$ found that body fat percentage values obtained with the BIA and skinfold methods correlated strongly with the values of DXA in non-obese individuals.

Although the skinfold equation of Durnin and Womersley (1974) yielded body fat percentage values of $26.4 \pm 4.2 \%$ and $36.9 \pm 3.3 \%$ for males and females respectively, it provided lower values than the ones found by DXA in the present study, the underestimation was more determinant in men 10.2\% compared with the DXA measurements. Our findings were consistent with previous studies that reported that skinfold equations do not accurately predict body fat percentage when compared with the reference method of DXA. ${ }^{7,24}$ On the other hand, our results were different of researchers who reported that body fat percentage derived from skinfold measurements do accurately predict fat percentage when compared with DXA. 6,25

Possible reasons why skinfolds underestimate the body fat percentage were described in detail, 20,26 and other authors have revealed several problems in the past, statistical research designed to predict fat percentage from skinfolds and anthropometric measurements, including overly homogeneous and insufficient samples, technical skill or level of fatness. ${ }^{27} \mathrm{~A}$ further problem is the number of independent variables of the participants, which invalidates the use of linear regression equations to analyze. Inter- and intraobserver measurement error, caliper calibration, and site selection variability may further decrease the reliability of the skinfolds method. Moreover this problem is major in the case of thicker skinfolds. Actually there is no anthropometric equation using skinfolds for obese people, only equations using circumferences and diameters. $^{5}$

Difference between skinfolds and DXA in this study may have been resulted by the skinfold prediction equations, because these equations were based on cross-validation with the two-compartment reference method of underwater weighing instead of the three compartment method (DXA), or multicompartment reference methods. ${ }^{9}$

The presented results in this study were limited to the equipment, which was used, so as it was proven before, even within the same technique, for example DXA, with different devices, different results can be obtained, ${ }^{28}$ as the proprietary algorithm for the bioimpedance devices can also explain the differences.

To the best of our knowledge, there are only three studies that investigated the change obtained by different methods, before and after an intervention in overweight or obese subjects. 22,29,30 However, none of them showed the method of skinfolds as one of the comparison methods and their results are controversial. Our data indicate that although there is much variance between subjects, BIA and DXA should be preferred to the skinfolds.

\section{CONCLUSION}

There are notable differences between the values obtained with DXA and other measurements (BIA and SK), but the differences in the change of fat were comparable. However, SK method seems to underestimate real changes, therefore DXA and BIA can be better and effective tools 
to measure change in fat percentage and fat mass during a weight loss program in overweight subjects.

\section{ACKNOWLEDGMENT}

The PRONAF Study takes place with the financial support of the Ministerio de Ciencia e Innovación, Convocatoria de Ayudas I+D 2008, Proyectos de Investigación Fundamental No Orientada, del VI Plan de Investigación Nacional
2008-2011, (Contrac: DEP2008-06354-C04-01) and financed in part by the Coordenação de Aperfeiçoamento de Pessoal de Nível Superior - Brasil (CAPES) - Finance Code 001.

\section{All authors declare no potential conflict of interest related to this article}

AUTHORS' CONTRIBUTIONS: Each author made significant individual contributions to this manuscript. EAC (0000-0002-4557-2921) and PJB (0000-0002-1631-8182) performed the statistical analysis and drafted the manuscript; BS (0000-0002-9987-0916), CGC (0000-0002-3879-0293) and MDC (0000-0003-3805-7195) participated in its design and coordination and drafted the manuscript; PJB (0000-0002-1631-8182) conceived the study. All authors have read and approved the final version of the manuscript and agree with the authors order of presentation. *ORCID (Open Researcher and Contributor ID).

\section{REFERENCES}

1. Addo OY, Pereira MA, Himes JH. Comparability of skinfold thickness to DXA whole-body total fat in their associations with serum triglycerides in youths. Eur J Clin Nutr. 2012;66(9):989-93.

2. Mally K, Trentmann J, Heller M, Dittmar M. Reliability and accuracy of segmental bioelectrical impedance analysis for assessing muscle and fat mass in older Europeans: a comparison with dual-energy $X$-ray absorptiometry. Eur J Appl Physiol. 2011;111(8):1879-87.

3. Hemmingsson E, Udden J, Neovius M. No apparent progress in bioelectrical impedance accuracy: validation against metabolic risk and DXA. Obesity (Silver Spring). 2009;17(1):183-7.

4. McNeill G, Fowler PA, Maughan RJ, McGaw BA, Fuller MF, Gvozdanovic D, et al. Body fat in lean and overweight women estimated by six methods. Br J Nutr. 1991;65(2):95-103.

5. Heyward VH, Stolarczyk L. Applied body composition assesment. 1a ed. Champain, IL: Human Kinetics; 1996.

6. Clark RR, Bartok C, Sullivan JC, Schoeller DA. Minimum weight prediction methods cross-validated by the four-component model. Med Sci Sports Exerc. 2004;36(4):639-47.

7. Watts K, Naylor LH, Davis EA, Jones TW, Beeson B, Bettenay F, et al. Do skinfolds accurately assess changes in body fat in obese children and adolescents? Med Sci Sports Exerc. 2006;38(3):439-44.

8. Leahy S, O'Neill C, Sohun R, Jakeman P. A comparison of dual energy X-ray absorptiometry and bioelectrical impedance analysis to measure total and segmental body composition in healthy young adults. Eur J Appl Physiol. 2012;112(2):589-95.

9. Toombs RJ, Ducher G, Shepherd JA, De Souza MJ. The impact of recent technological advances on the trueness and precision of DXA to assess body composition. Obesity (Silver Spring). 2012;20(1):30-9

10. Beeson WL, Batech M, Schultz E, Salto L, Firek A, Deleon M, et al. Comparison of body composition by bioelectrical impedance analysis and dual-energy X-ray absorptiometry in Hispanic diabetics. Int J Body Compos Res. 2010;8(2):45-50.

11. Muesing RA, Forman MR, Graubard BI, Beecher GR, Lanza E, McAdam PA, et al. Cyclic changes in lipoprotein and apolipoprotein levels during the menstrual cycle in healthy premenopausal women on a controlled diet. J Clin Endocrinol Metab. 1996;81(10):3599-603.

12. National Institutes of Health. Clinical guidelines on the identification, evaluation, and treatment of overweight and obesity in adults: executive summary. Expert Panel on the Identification, Evaluation, and Treatment of Overweight in Adults. Am J Clin Nutr. 1998;68(4):899-917.

13. Zapico AG, Benito PJ, Gonzalez-Gross M, Peinado AB, Morencos E, Romero B, et al. Nutrition and physical activity programs for obesity treatment (PRONAF study). methodological approach of the project. BMC Public Health. 2012;12(1):1100

14. Durnin JV, Womersley J. Body fat assessed from total body density and its estimation from skinfold thickness: measurements on 481 men and women aged from 16 to 72 years. Br J Nutr. 1974;32(1):77-97.

15. Malek MH, Berger DE, Housh TJ, Coburn JW, BeckTW. Validity of VO2max equations for aerobically trained males and females. Med Sci Sports Exerc. 2004;36(8):1427-32.
16. Lukaski HC, BolonchukWW, Hall CB, Siders WA. Validation of tetrapolar bioelectrical impedance method to assess human body composition. J Appl Physiol. 1986;60(4):1327-32.

17. Deurenberg P, Andreoli A, Borg P, Kukkonen-Harjula K, de Lorenzo A, van Marken Lichtenbelt WD, et al. The validity of predicted body fat percentage from body mass index and from impedance in samples of five European populations. Eur J Clin Nutr. 2001;55(11):973-9.

18. Weir JP. Quantifying test-retest reliability using the intraclass correlation coefficient and the SEM. J Strength Cond Res. 2005;19(1):231-40.

19. Shaw KA, Srikanth VK, Fryer JL, Blizzard L, Dwyer T, Venn AJ. Dual energy X-ray absorptiometry body composition and aging in a population-based older cohort. Int J Obes (Lond). 2007;31(2):279-84.

20. Duz S, Kocak M, Korkusuz F. Evaluation of body composition using three diVerent methods compared to dual-energy X-ray absorptiometry. Eur J Sport Sci. 2009;9(3):181-90.

21. Neves EB, Ripka WL, Ulbricht L, Stadnik AM. Comparison of the fat percentage obtained by bioimpedance, ultrasound and skinfolds in young adults. Rev Bras Med Esporte. 2013;19(5):323-7.

22. Li YC, Li Cl, Lin WY, Liu CS, Hsu HS, Lee CC, et al. Percentage of body fat assessment using bioelectrical impedance analysis and dual-energy $\mathrm{X}$-ray absorptiometry in a weight loss program for obese or overweight Chinese adults. PLoS One. 2013;8(4):e58272

23. Erselcan T, Candan F, Saruhan S, Ayca T. Comparison of body composition analysis methods in clinical routine. Ann Nutr Metab. 2000;44(5-6):243-8.

24. Barbosa AR, Santarem JM, Jacob Filho W, Meirelles ES, Marucci JM. [Comparison of body fat using anthro pometry bioelectrical impedance and DEXA in elderly women]. Arch Latinoam Nutr. 2001;51(1):49-56.

25. Vasudev S, Mohan A, Mohan D, Farooq S, Raj D, Mohan V. Validation of body fat measurement by skinfolds and two bioelectric impedance methods with DEXA--the Chennai Urban Rural Epidemiology Study [CURES-3]. J Assoc Physicians India. 2004;52:877-81.

26. Wang Z, Deurenberg P,Wang W, Pietrobelli A, Baumgartner RN, Heymsfield SB. Hydration of fat-free body mass: review and critique of a classic body-composition constant. Am J Clin Nutr. 1999;69(5):833-41.

27. Jackson AS, Pollock ML, Ward A. Generalized equations for predicting body density of women. Med Sci Sports Exerc. 1980;12(3):175-81.

28. Ackland TR, Lohman TG, Sundgot-Borgen J, Maughan RJ, Meyer NL, Stewart AD, et al. Current status of body composition assessment in sport: review and position statement on behalf of the ad hoc research working group on body composition health and performance, under the auspices of the I.O.C. Medical Commission. Sports Med. 2012;42(3):227-49.

29. Pietilainen KH, Kaye S, Karmi A, Suojanen L, Rissanen A, Virtanen KA. Agreement of bioelectrical impedance with dual-energy $\mathrm{X}$-ray absorptiometry and MRI to estimate changes in body fat, skeletal muscle and visceral fat during a 12-month weight loss intervention. Br J Nutr. 2013;109(10):1910-6.

30. Aslam M, Eckhauser AW, Dorminy CA, Dossett CM, Choi L, Buchowski MS. Assessing body fat changes during moderate weight loss with anthropometry and bioelectrical impedance. Obes Res Clin Pract. 2009;3(4):209. 